\title{
A microcosm of English
}

The first decade was hardly dull.

When ET began in 1985, it was a magazine intended to help bridge three gaps: between the scholarly and lay worlds, between scholars of language and literature, and between native and nonnative users of the language. In 1988, it changed to a 'magazinecum-journal' with a more compact format that made librarians happy, and published articles which, under gentle but persistent pressure from its academic contributors, steadily incorporated more standard scholarly apparatus. And well before 1994 it had become a much-cited academic journal that, while attracting cutting-edge articles on major issues, has kept its original aim of being informative, accessible, flexible and entertaining.

As many people have pointed out, ET has always tried to be all things to all readers, intent on covering in 64 pages per issue a vast terrain and a host of concerns worldwide. In the process it has naturally been 'multicultural' - a term that for some is a tool, for others a slogan, and others still a threat. At the back of this issue are three detailed ten-year indexes - chronological, thematic, and authorial - that demonstrate the extent to which we have been covering life, the universe and everything linguistic. When our publisher looked at it recently, she called it 'a microcosm of what has interested people about the English language over the past ten years!' I would like to thank all those who have created that microcosm - and invite them to carry on building it.

To help with this work Cambridge University Press has appointed an Editorial Board whose members are François Chevillet, David Crystal, Alan Kaye, Loreto Todd and Katie Wales. $E T$ has always engaged when appropriate in peer review, and the appointment of the Board will not only make this involvement more evident but also help us explore new possibilities. David Crystal has already done sterling work as Consulting Editor since ET's conception, and it is good not only to have him continue as a Board member but also to have four distinguished colleagues with whom he and I can share the load. Watch this space.

Tom McArthur

The editorial policy of English Today is to provide a focus or forum for all sorts of news and opinion from around the world. The points of view of individual writers are as a consequence their own, and do not reflect the opinion of the editorial board. In addition, wherever feasible, ET generally leaves unchanged the orthography (normally British or American) and the usage of individual contributors, although the editorial style of the joumal itself is that of Cambridge University Press.

(c) Cambridge University Press 1995 No contents may be reproduced by any means without the permission of Cambridge University Press.

English Today (ISSN 0266-0784) is a quarterty.

Publisher: Cambridge University Press, Edinburgh Building,

Shaftesbury Road, Cambridge CB2

2RU. Telephone (01223) 312393

Subscriptions: the current annual subscription price for four issues for libraries and institutions is $\mathbf{4 4 9}$ outside North America; £24 for individuals; $\Sigma 19$ for students and the retired; airmail $\Sigma 11$ per year extra. Apply to Jane Crossland at the above address.

Advertising Sales: write to the Advertising Promoter at the above address.

USA, CANADA AND MEXICO:

Publisher: Cambridge University Press, 40 West 20th Street, New York, NY 10011-4211. Telephone (212) 9243900.

Subscriptions: the current annual subscription price in USA, Canada and Mexico for libraries and institutions is $\$ 79 ; \$ 38$ for individuals; $\$ 26$ for students and the retired. Copies are air-freighted to New York to arrive with minimum delay. Apply to Joseph D. Hranek at the above address.

Advertising Sales: write to Elaine Rowland at the above address.

Second class postage paid at New York, NY and at additional mailing offices.

POSTMASTER: send address changes in USA, Canada and Mexico to English Today, Cambridge University Press, 110 Midland Avenue, Port Chester, New York, NY 10573-4930.

Japanese prices for institutions (including ASP delivery) are available from Kinokuniya Company Ltd, P.O. Box 55, Chitose, Tokyo 156, Japan.

Letters to the Editor: write to Dr Tom McArthur, Editor, English Today, 22-23 Ventress Farm Court, Cherry Hinton Road, Cambridge CB 4HD, UK. TelFax 01223245934

A call for papers: in $E T$ 's files we have cuttings/clippings from a wide range of British and North American newspapers, and a scattering of material from many other sources. If readers would care to add to our files by sending in occasional (titled and dated) materials from their local newspapers, etc., this would be a great help in widening the range of usage which we can quote.

Printed in Great Britain at the University Press, Cambridge 